\title{
INTESTINAL HELMINTHIASIS IN BANGLADESH, THE CLINICAL FEATURES
}

\author{
S. Ahmed*
}

\section{Introduction}

Intestinal helminthiasis is one: of the mmmonest gastrointestinal djseases in East Pakistan. Patients of different age groups and strata with varlous manifestations of gastrointesinal, carliovascular, respiratory and other systems due to helminthic infections sexth mediral advice ejther in private clinics or in hospitals everyday. Not umcommonly patients are admitted in hospitals with serious complications such as at:ute intestinal uldstuction, performation with peritionitis, severe anaenula with hear' tailure: gross malnutrition. Ioxaemia and convulsions. The climate, porous and motsi soll of Bangladesh are very suitable for growth of larvac of soll transmitted he:lininths e.g. Ascaris lumbricoldes. hookworm etc.

Vast majority of our population are illiterate and engaged in farming. marketing and allied occupations. They live in rural areas of unhyglentc surroundings. There is no proper arrangement. for disposal of night soll in villages and they make generous use of the river and pond waters contiminiterd with human excreta. As in-most villeges and slum areas of unplanned growing towns. the people are crowded into ljmited living space, thus encouraging spread and propagation of helminthic diseases. Unhygienic soclal conditions. apathy in the gehlevements of positive health. iynorance, prejudices and poot eortomic status, all added to the propagation of belminthic infections. Infurtumately the helminthic infections are at times considered by the commith mass as wumething unavotdable and nothing unusual.

No comprehensive survey has yet been done to find oul. the incidence of dilferent belninthic infections in our country. The reports published so far in different joumals are not suffeient to give an over all idea about the true picture of helminthis: inlections in Langladesh. The survey report of Kutitz (1960) who issestigated the incidence of intestina! patasiles in school children in the vicinlty of Dhaka city revealed a picture of helminthic: inlections in a very small selected age group only. Muazzan et al [1961] reported on their findlngs in Dhaka and Rajshahl about intestinal parasites among selected cases with gastroiritestinal symptoms referred by clinttans and from hospital wards. The figures of Kunll wers 60\% ascariasis and 47\% hookworms in 300 school children. Muatzarn showed incictence of $33.9 \%$ ascariasis and 28.2\% hookworm cases in $242 \mathrm{l}$ sichols examined. According to chowdtury (1965) stools examination of his cases revealcd helminthic: infesiations with Ascaris in $52 \%$, hookworn in $6 \%$ and $\mathrm{T}$. Trichiura in $20 \%$ of his cases. From these reports and from clinical observations it appears that ascariasis.

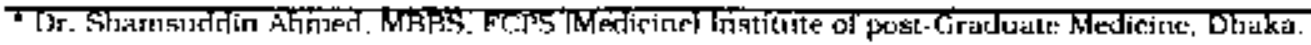


bookworm diseases. trichurlasis are quite common. The taeniasis, Hyntenolopes nani infesiation. fasciolopsiasjs and stribngloidtasis are uncomtion in East Pakistan. Though enterobinsis is quite common here, incidence showm in their serics was very low. It might be due to the lact that stool exammation is not the sujtable method for diagnosing threadowra infection. If scolch cellulose tape method is used. the incidence will delinitcly be rnuel hitgher.

To avoid complications and to eradicate the worms from the iffected persuns ind to prevent spread of the diseases, early diagnosis is nocessary. Only stool cxanunation can help diagrosis of most of the cascs and it is the simplest and easiest method that can be carried oul every where cither in huspltal or in private clinics. It is intercsing to record here the obstrations by Islam et al (1962). Of the 162 cases who were suspected to be sulfering from peptic ulcer, 25.9\% had $A$ lumbricoldes wh organic Iesion and $28,3 \%$ cases bacf ascartasis without organic lesion of stomach and duodenum. These authors stated that ascariasis and peptic ulcer were often difficult to distinguish on clinlcal grounds and that stonl cxaminatfons were not always reliable in the ditection of the prescnce of infection with Ascars lumbricoides. They conchuded that in a good proportion uf cases ascartasis could be delected by $\mathrm{X}$ ray cxaniriation 2.3 hours alter a barjum swallow. Unfortunately some of the petichts do not usisally seck advice untl and unless some complication arises.

Treatment of uncomplicated helminthic: infestations is purely medical and the pallents can be treated without hospitalization. only tew complicated cases of ascariasis need surgical management. The Importance of timely diagnosis and adequate 1 reatment of hclminthiasis can not therefore be lypored.

The purpose of this article is to bring home our present day knowledge about the clitical features of helminthiasis.

\section{Morbidity and mortality}

\section{Ascaris lumbricoldeg :}

The adult worns nay sause a chronis: intestinal catarth. Their migration may lead to intestina] perforation and perilonitis, especially in cases associated with typhoid or other ileerations, to appendicular obstuction. blockage of the bile duct leading to jaundice, pancrealt: duct obstruction giving rise io inflammatory changes in the pancreas. Inlestinal obstruction may be produced by impection with a large bunch of worm, or by intussiusception due to the worm. Orcasionaly, the worm naty pass up the oesophagus and pharynx, and then go down the larynx ausing respitatory obatruntion. In uromen, they may invade the genurative tract. and have been found encysted in the Fallopain Tubes. Other complications such as hepalic absecss. middle ear obst nuction, lacrymal duct obstruction. latal pulmonary infection-all are reported and published in varitus jouruals. It hiss also been eriphaslzed that the presence of iscarisis Iumbricoides constitute a potentlal hazard to otherwise roulirte. surgical proceedings.

Very interesting post mortem findings were described by Muazzan. Khaleque and Ibrahim (1960). They described the comdition as hepatte ascariasis. Large number of affult Ascaris wert: found in bile dict. hepatle durt and also one in gall bladder. 
There were a large alsscess in the liver and two other granulonatous areas with coited up round wamis.

The mortality from uncomplikitcd Ascaris infection is almost nil. But complications may be caused by morating worms and even death may occur.

\section{Hookworms :}

The hookworms produce their bamilin effect on the system chiefly by loss of blood caused by them, though some authers believe that they may secrete some toxins. To produce any harmtul effect in the host, the parasites must be in sulflcient number. The number ol worms may very from 10-25 in very light infection lo scveral thousands in very heavy jnfection. But it must be admitted that the severity of symptoms is not always proportionate to the number of worms. It should be remembered that a light infectlon in co-existence with malatia. kala-azar or dysentery may prodice a serious disterbance to the health (Manson- Bahr. 1966).

The characteristic pathological lesions, which the worms produce, are ccchymoses and small erosions in the intestiual mucosa, in the centres of which they are scen attached. There are usually more erosions in the mucosa than the number of worm, tndicating that they shifl from one point to another. The body of the host becomes anaemic and often ocdematous. Heart may be dilated and may slow evidences of fatty degeneration and fajlure. Liver and kidneys also show latty change. The anaemia is generally hypucthromic microcytic but macrocytic ànaemia may occur in certain percentage of cascs. Coagulation time $1 s^{-}$prolonged. Eosinophil cells increased.

The bone marrow in hookworm infection associated with iron defeciconcy anaeinia show moderate erythroblastic hyperplasia, with an erythrocyte myelocytc: ratio in the victinity of one.

Besides an increase in eosinophils. there is no other abmomality in the granulocyte series. The number of magakaryoytes is either nonmal ar silghtly increased. Ironstained hacmosiderin is absent. Megaloblastic prolteralion is occassionally abserved and hypoplastic malarow is a rare event.

The prognosis is good if the thesease is detecled carly and properly treated. Children may suffer from mental and physical retardation. Due to larva! invasion there Is dematitss, vesiculation and pastulation may ersue and even extensive ulceration may occur.

It is found that hookworm dtsease exerts a deleterious influence on pregnancy. and that in heavily infected districts it is the most common cause of repcated abortions and miscarriage. Moreover. a heavy matemal and latal trortality is associated with it. and early intermptions of pregnancy and neonatal deaths are also included among its effects.

Women who are haevily infected show a predispestltons to taxaemias. such as precrlampsia and nephritis. The average mortality is low, but death may occur from syncope, darthoca or asthenda or some Intercurrent affections. (Manson-Bahr. 1966). 


\section{Enteroblus vermicularis :}

The significant pathology is the irrtation caused by the gravd females around the anus. The migrating females may enter tnto the female gential tract and female urethra producing, inflammation. These worms even enter into periloneal cavity through Fallopain tubes. Salpingitis and apperdicits may occur. Pelvie granuloma caused by Enterbius vermicularis are reported in world literature through the cases are very Itnuted. All recorded cases of pelvic: granuloma occured in females. (Brooks et al. 1962 and Wh 10 report, 1964l.

\section{Trichurls trtehiuria :}

This worm produce no remarkable pathology but in heavy infection chrontc diarthoca and even rectal prolapse may occur in chiktren Wung \& Beaver, 1952).

\section{Strongyloides sterooralis :}

A few isolated rases of heavy auto- infection resulting in severe disease and even death are reported fron endemic areas of the world. In mild cases there ts catarshal enteritis with mucus secretion and sometines haemorrhage and microulceraton. In intermediate forms there may be oedematous enteritis with atrophy of the mucosa and oedema of the sulmrincosa. Serious forms are characterised by ulcerous entertis. The most pronounced lesions orcur in the skirl. either as a result of local penetration or sensilivity reactions, "Creepirig eruption" occur in case of strongyloddes infection due to migration of larvae in the sub-epithelial skin layers.

\section{Tape worms :}

The adult worms while living in the intestine usually do not give rise to any deflntte pathology. Hymeriolopes nana in heavy infertion are stated at times to cause severe toxaemia, diarrhoea. epileptiform convulsions in children in whom they are usually found. If man swallows eggs. liberated from disintegrating gravid segments of $T$. Solium of his own or another person, he develops cysticermsis. The cysticerct in man are lodged in the connective tissues, voluntary muscles. and the central nervous system. Cysticercus in brain is surrounded by neuroglta, lymphocytes and few plasma cells. When dead and degeneratert it acts as irrtant and focal necrosis around the cyst may occur and later becomes calcified. They rarely develop in the spinal cord.

\section{Fasciolopsis buskj:}

The parasites live in, and alfect, the intestine particularly the doudenum. Foc: of inflamnation form at the site of attachment. which sometimes proceed to haemorrhage or abscess fomation. In heavy infections oedema of face. abdominal wall and lower extremities may occur. The condition sometimes progress to prostation and death. In children disturbances ol growth and development are observed.

\section{Methods of Study :}

Flfty cases of different age groups, sexes and oxupations presenting with manifestutions of intestinal helninthlasis were studied. The patients suffering from some other urganic diseases of gartro-inientimol tract with incidenlal helminthic 
infestation were nol included in this siries as the atm of studies was based on clinical aspecis of helminthasis.

The criteria for diagnosis were clubeal blstory of the pattent. physical fondtngs. stool examination, blood examinatjon. sputun cxamination. $X$-ray chest and barium meal $x$ - ray ol bestro- intestinal tracts and identification of adult worms afier antheimintics.

The: following particulars were noted in each casc:-

1. Aye

2. $\operatorname{Sex}$

3. Orcupation.

4. Duration ol Illness

5. Presenting syniptoms

6. Muysical sings

7. Demonstration of ova,larvae or adult worm in stools.

b. Fercentage of haemoglobin.

9. 'lype of anaema

10. Total WBC count \& percentage of eosinophils.

11. Jesults of treatment.

Incidence of different types of helminths in this series of tifty cases is given below in Table-1.

Table 2 shows the incidence in combination of different helminths.

Table-1

\begin{tabular}{|c|c|c|}
\hline Types of helminths & $\begin{array}{r}\text { Number of } \\
\text { patierts }\end{array}$ & Perrentage \\
\hline Ascaris lumbricotdes (only) & 15 & $30 \%$ \\
\hline Ascanis + E. vermicularis & 3 & $6 \%$ \\
\hline Ascaris + Hookwornis & 5 & $10 \%$ \\
\hline Ascaris + T. Trtchitua & 6 & $12 \%$ \\
\hline Ascarts + Hookworms + T. trichiura & 4 & $8 \%$ \\
\hline Hokworms [only] & 7 & $14 \%$ \\
\hline Huokworms + T, trehitura & 3 & $6 \%$ \\
\hline E. vermicularis [onyl & 4 & $8 \%$ \\
\hline Strongloides strcoralis & 1 & $2 \%$ \\
\hline Teenia & 1 & $2 \%$ \\
\hline Fasclolopsis buski & 1 & $2 \%$ \\
\hline
\end{tabular}

Total

Incidence of Ascarts. Hownorms, $\Gamma$. Irchiura and $E$. vemicularis tuken separately. 


\begin{tabular}{lcc}
\hline \multicolumn{1}{c}{ Types of helminths } & Number of cases & Percentage \\
\hline Ascaris lumbricoides & 33 & $66 \%$ \\
I ookworms & 19 & $38 \%$ \\
T. trichitura & 13 & $26 \%$ \\
E. venntcularts & 7 & $14 \%$
\end{tabular}

\section{Age Incidence :}

The age incidence of patients. in this series, with manifestations of Intestinal helminthic infections vartes from one to seventy years (Table-3). The number of cases include the multiple belminthic infectiolns.

\section{Tuble-3}

Age in Ascaris Hook- Trichuris E. Vermi Strong. Taenia F. Busk.

Yeaes. lubmricoldes woms. Iricuhiura, culrais stercoralis.

\begin{tabular}{|c|c|c|c|c|c|c|c|}
\hline $1-5$ & 13 & Nil & 2 & I & Nil & Nit - & $\mathrm{Nil}$ \\
\hline $6-10$ & 9 & 1 & 3 & 1 & $"$ & 14 & 1 \\
\hline $11-15$ & 5 & 1 & $\mathbf{l}$ & Nil & ". & ". & Nit \\
\hline $16-20$ & 2 & 2 & 1 & 1 & $\cdots$ & $"$ & $"$ \\
\hline $21 \cdot 25$ & 1 & 3 & 2 & 1 & $H$ & $"$ & " \\
\hline $25-30$ & 1 & 3 & 1 & $\mathrm{~N}$ il & $I$ & י & $\cdot$ \\
\hline 31-35 & Nil & 3 & 1 & 1 & Nil & 1 & $"$ \\
\hline $36-40$ & 1 & 2 & 1 & Nit & $"$ & N11 & " \\
\hline $41-45$ & NI & 2 & 1 & $"$ & ". & $"$ & $\cdot$ \\
\hline $46-50$ & 1 & 1 & NI & 1 & " & - & • \\
\hline $51-55$ & Nu & $\mathrm{Nil}$ & $"$ & Nil & $"$ & $"$ & $"$ \\
\hline $56-60$ & $"$ & $"$ & $"$ & -1 & ". & $n$ & • \\
\hline $61-65$ & $"$ & 1 & $"$ &. & " & $n$. & $"$ \\
\hline $66-70$ & $"$ & NI & $"$ & 1 & " & 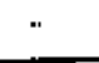 & $"$ \\
\hline Toral : & 33 & 19 & 13 & 7 & ] & ] & 1 \\
\hline
\end{tabular}

Out of 50 cases 31 belong to the ayse group 1 i $t$ lo ycars.

\section{Sex incidence :}

Sex incidence in difierent. helminthe (intestinal) infections shown below learh type of helminths laken separately]. 


\begin{tabular}{|c|c|c|c|c|}
\hline Types of helninths & $\begin{array}{c}\text { Male } \\
\text { patient }\end{array}$ & $\begin{array}{l}\text { Percentage } \\
\text { [approx] }\end{array}$ & $\begin{array}{l}\text { Female } \\
\text { Patient }\end{array}$ & $\begin{array}{l}\text { Percentage } \\
\text { (approx) }\end{array}$ \\
\hline Ascaris lumbrtcoldes & 17 & $51.52 \%$ & 16 & $48.48 \%$ \\
\hline Hookworms & 16 & $84.21 \%$ & 3 & $15.79 \%$ \\
\hline Trichuris trichiura & 7 & $53.85 \%$ & 6 & $46.15 \%$ \\
\hline E. vermicularis & 4 & $57.14 \%$ & 3 & $42.86 \%$ \\
\hline Stromh. stercoralis & ] & $100 \%$ & Nil & $\cdot$ \\
\hline Taenia & NII & - & 1 & $100 \%$ \\
\hline F, buski & 1 & $100 \%$ & Nil & - \\
\hline
\end{tabular}

\section{Occupational incidence :}

Table 5 shows the occupational incidence :

Table-5

\begin{tabular}{|c|c|c|}
\hline Occupation & Number of Patients & Percentage \\
\hline Farmers & 25 & $\mathbf{5 0 \%}$ \\
\hline Labourers & 9 & $18 \%$ \\
\hline Students & 5 & $10 \%$ \\
\hline Businessman & 3 & $6 \%$ \\
\hline Miscelleneous & 8 & $16 \%$ \\
\hline Total : & 50 & $100 \%$ \\
\hline
\end{tabular}

Duration of illness :

Table 6 shows the dnration of ilness 
Table-6

\begin{tabular}{|c|c|c|c|c|}
\hline & \multirow{2}{*}{$\begin{array}{c}\text { Number of cases } \\
3\end{array}$} & \multirow{2}{*}{$\begin{array}{c}\text { Percentage } \\
6 \%\end{array}$} \\
\hline \multicolumn{3}{|c|}{$\begin{array}{l}\text { Duration of fllness } \\
1-2 \text { Months }\end{array}$} & & \\
\hline $2-3$ & $n$ & & 19 & $38 \%$ \\
\hline $3-4$ & $"$ & & 5 & $10 \%$ \\
\hline $4-5$ & $"$ & & 3 & $6 \%$ \\
\hline $6-7$ & $"$ & & 3 & $6 \%$ \\
\hline $7-8$ & $"$ & & 4 & $8 \%$ \\
\hline $8-9$ & $"$ & & 2 & $4 \%$ \\
\hline 9.10 & $"$ & & 1 & $2 \%$ \\
\hline $10-11$ & $"$ & & 1 & $2 \%$ \\
\hline \multicolumn{3}{|c|}{11 Mon 1 Year } & l & $2 \%$ \\
\hline $1-2$ & $"$ & & 1 & $2 \%$ \\
\hline $2-3$ & r & & 1 & $2 \%$ \\
\hline $3-4$ & " & & 1 & $2 \%$ \\
\hline $4-5$ & $r$ & & 1 & $2 \%$ \\
\hline $5-6$ & $"$ & & Nil & 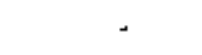 \\
\hline $6-7$ & $"$ & \multirow{4}{*}{+} & 1 & $2 \%$ \\
\hline $7-8$ & $"$ & & 1 & $2 \%$ \\
\hline $8 \cdot 9$ & $"$ & & 1 & $2 \%$ \\
\hline $9 \cdot 10$ & " & & 1 & $\overline{2} \%$ \\
\hline \multicolumn{3}{|l|}{ Total : } & 50 & $100 \%$ \\
\hline
\end{tabular}

\section{Presenting Symptoms:}

The presenting symptoms in children differs considerably from that of adults. So these are shown separately.

The presenting symptoms in children:

1. Abdominal paln.

2. Diarrhoea.

3. Dysentery.

4. Flatulence.

5. Nausea.

6. Vomiting.

7. Passage of worm through mouth and nose.

8. Increased salivation.

9. Loss of appetite.

10. Increased appetite.

11. Geophagy.

12. Conșlipation.

13. Passage of wort or segments with stool.

14. Tecth grinding. 
15. Fever.

16. Cough.

17. Prurtutus.

18. Urticania.

19. Proking of the nose.

20. Convuisions.

The symptoms produced in younger children were described by the mathers of the children or attendents.

Presenting symptoms in adults :

1. Abdominal pajn or discomfort.

2. Increased salivation.

3. Nausea.

4. Vomiting.

5. Passage of worm with stool or vomit.

6. Loss of appetite.

7. Dlarthoea or constipation or both.

8. Prurtus ani.

9. Low grade fever.

10. Giddiness.

11. Palpitation.

12. Shortness of breath.

13. Lassitude.

14. Syncope.

15. General weakness.

16. Disturbance of sleep.

17. Buzzing in theear.

18. Swelling of legs.

The patients suffering from severe anaemla due to hookworm infectron complatned mainly of giddiness, palpitation, shortness of breath, lassitude, syncopal attacks and general weakness in addition to gastro- intestinal symptoms [Table-7]. 
Table-7

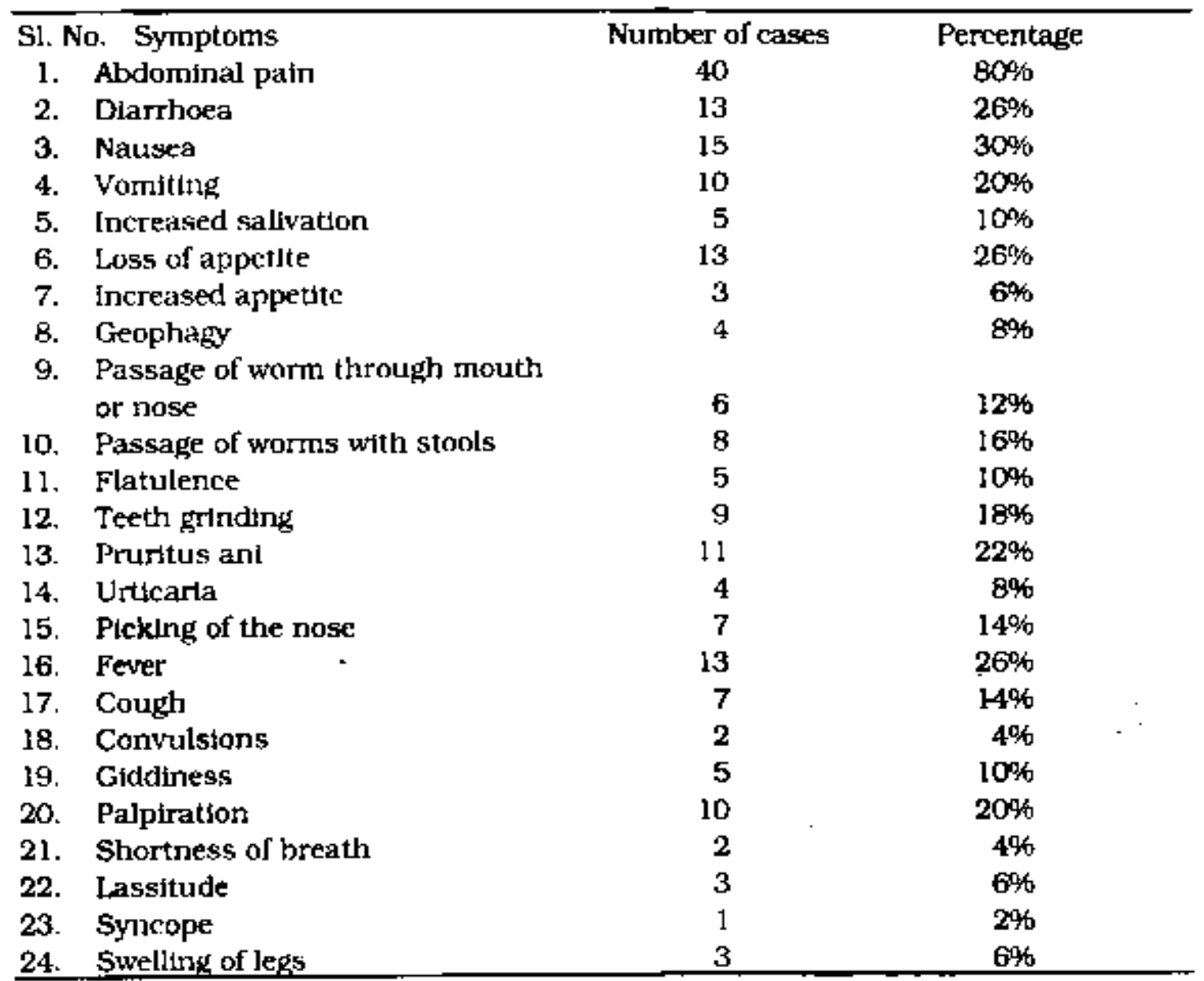

Almost all patients had multjple symptoms.

\section{Phyolen algne:}

Physical slgns in chilidren :-

1. Poor nutrition.

2. Stunted growth.

3. Pallor and anaemia.

4. Protuberent abdomen with lumber lordosis.

5. Dehydration.

6. Irrttabllty and listlessness.

7. Oedema liggs.

8. Fever.

9. Convulsions.

10. Foul breath. 
11. Enlarged itver.

12. Feelings of worms per abdomen.

13. Vtsible peristalsis in abdomen.

14. Crepttations in Iungs.

Physical signs in adult mainly produred by hookworn infections with severe anacmia and following signs were found:-

1. Putfy lace.

2. Pallor and anatemia.

3. Ankle oedema.

4. Kollonychia.

5. Signs of cardtac dilaton and failure.

6. Mental apathy atc.

Incidence of physical signs in 50 cases-both chilfren and adults combined (Table-8) are gfven below :

Table- 8

Sl, No. Physical signs

1. Poor nutrition :

2. Stunted growth

3. Pallor and anacmfa

4. Putfy face

5. Mental apathy

6. Dehydration

7. Koilonychia

8. Irtitability \& listlessness

9. Oedema legs

10. Fever

11. Convulsions

12. Foul breath

13. Enlarged liver

14. Protuberent stodrmen

15. Feeling of worn per abdomen

16. Visible peristalsis $1 \mathrm{n}$ abdonen

17. Crepitation in lungs.

18. Signs of cardiac dildatation

Number of patients

21

13

38

5

3

3

2

12

5

4

2

4

6

9

7

4

7

4
- Percentage

$42 \%$

$26 \%$

$76 \%$

$10 \%$

$6 \%$

$6 \%$

$4 \%$

$24 \%$

$10 \%$

$8 \%$

$4 \%$

$8 \%$

$12 \%$

$18 \%$

$14 \%$

80

$14 \%$

$8 \%$

Almost all patients had muttiple sligns. 
Percentage of haemoglobin and eosinophil cells in peripheral Blood found in 50 cases. (table- 9 and 10 ) are given below :

\section{Table-9}

\begin{tabular}{lcc}
\hline $\begin{array}{l}\text { Haenloglobin } \\
\text { percentage }\end{array}$ & $\begin{array}{c}\text { Number of } \\
\text { cases }\end{array}$ & $\begin{array}{c}\text { Percentage of } \\
\text { cases }\end{array}$ \\
\hline $10-20$ & 2 & $4 \%$ \\
$21-30$ & 1 & $2 \%$ \\
$31-40$ & 5 & $10 \%$ \\
$41-50$ & 12 & $24 \%$ \\
$51-60$ & 25 & $50 \%$ \\
$61-70$ & 4 & $8 \%$ \\
$71-80$ & 1 & $2 \%$ \\
$81-90$ & $\mathrm{Nil}$ & - \\
$91-100$ & $\mathrm{Ni}$ & - \\
Total & 50 & $100 \%$ \\
\hline
\end{tabular}

Table-10

Eoșinophil

percentage

0 - 5

$6 \cdot 10$

$11 \cdot 15$

$16-20$

Total
Number of

cases

2

29

16

3

50

Percentage of
cases
$4 \%$
$58 \%$
$32 \%$
$6 \%$

$100 \%$

All the cases showed TWBC count normal except two children with lever and lung findings where TWBC count was above $12,000 / \mathrm{cmm}$.

\section{Descussion :}

Intestinal helminthiasis is extremely commion in Bangladesh where the dimatic condition, habit of the general nass, proverty and ignorance are very much helpful for spread of the disease. Ascariasis is more prevelent among children whereas hookworms in agricultural and other labourers. In so far as the impact of intestinal helminths on nutrition is known, it is clear that the principal eflect experienced on a public helath scale are depletion of iron. Consquently there is iron deficiency anaemta due to hookworms and impairment of protein nutrition caused by Ascarls and hookworms. The effects of $T$. trichlura infection on the ineidence of kwashiorkor and other protein malnutrition atated need further investigation. It is well knowm that kwashiorkor and some other malnu utt'ivilal conditions may be precipitated by 
an attack of diarrhoea or womiting with assorexda in those whose state of nutrition has been poor or marginal.

Helminthic infection as a whole can be vlewed as providing. by their prevelence, an index of a community's progress towards a desirable level of sanitation. It is true that high standard of living depend on high economic productivity and this in turn requires high levels of phystcal vigor and health. Thus helminths are important to whatever extent they detract from the vigor of the community. The most prevelent and most damaging helminths in East Pakistan are those of the solt-transmitted group specially Ascaris lumbricodes and hookwonns.

Treatment of the intestinal helminthiasis has become more simplified due to the discovery of newer less toxic or non toxic drugs. All the cases can safely be treated without much expenditure as only one or two doses of the drugs are necessary in majority of cases. To eradicate the diseases caused by helminthic infections needs much health education, proper disposal of night solis and treatment of infected persons. It is a gigantic problem. From the magnitude of the problems, it is suggested that thc country wide survey should be undertaken to determine the incidence and make a scheme for eradication.

\section{Conchusion}

The total number of patients in this series is small. Therefore. no firm conclusion can be drawn from this study. One thing is clear that helminthiasis is one of the most common cause of bowel troubles in Bangladesh. particularty due to Ascaris and hookworm infections and important cause of severe anaemiá In rural population due to hookworm. The extent to which the population of this country is assalled by intestinal worms is not generally apprectated. Majorty of the population harbour these creatures. While some of the worms may appear to have ittle effect on health, such unbidden guests can not fail to influence the nutritional state of thetr hosts. So, every physiclan and surgeon who have to deat with cases of acute or chronic abdominal conditlons should keep in their minds the possibility of helminthiasis.

\section{Bdbliotraphy}

Adams, A.R.D.\&Maegralth B.G. (1966). Clinical Tropical Diseases Fourth Edition E.B.S.L.\& Blackwell, Oxford.

Banerjee J.C. \& Bhattacharya P.B.1967. A Handbood of Troptcal Diseases. 6Ih Ed. Academid Publishers. Calcutta.

Chaudhury. S.A.1966. Kwastorkor in Easl Pakistan. Report, Pak. Med. Res.Cauncil, Karachi.

Chandier. A.C.1958. Introduction to Parasitology with spectal Ref. to the parasites of Man. Gth Ed. John. Wiley \& Sons.

Faust. E.C.\& Russel P.E. 1964.Crajg and Faust's A Clinical Parasllology 6th Ed. Lea.8 Febiger. Philadelphia.

Islam. N \& Haque,K.S. 1962. Ascariagis \& Pepttc Ulcer in Radiology. J. Trop. Med. \& Hyg. 65. 6-9.

Jung. R.C.. Beaver, P.C. 1952. Clinical Observation on T, trichiura Infection in Children. 
Paedialrics, $6,548-557$.

Kinalequc. A.K. \& Alam, K.s. 196.3. Hapelic Ciranuloma caused by Ascaris Ova. J. Trop. Med. Hyg. 66. 249.51.

Khan. A.K.\& Muazzam. M.G.1965. Honkworm infecilon in East Pzkisian \& Jts Treatment, Palk. J. Med. Jes. 4. 184-9.

Khandiker. R. K. Katblr. A. . . ‥ $\alpha$ Hique. A. 1968. Incidence and cuntribution of Trichuris Irithhlura intestation in (;. T. distorders. J. Trop. Med. and liyg. 71. No.7

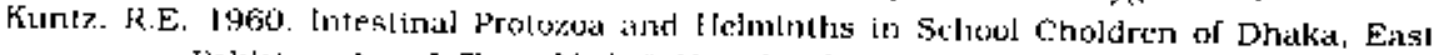
Pakistin. Am. J. Trop. Med. Ilys. 9. 168-172.

Mansort-Aahr. Sir P.H. 1 g66. Manson's Tropical Diseases lGth Ed. Baillerre Tindan and Cassod.

Muazzan, M.G., Khaleque. K. A. \& Ibrahim. M. 1960. Hepatic Ascanasis. J. Trop. Med. and J1yg. $63.95-7$.

Ochsner et al. 1949. Complicutions of Ascirdasls kequirtng Surglcal Treatment. Am. J. Dis. Clildd. 77. 336-486.

Stoll. R. N. 1957. Helmiththic infection as the cause of Disability and Discase. AJnulal

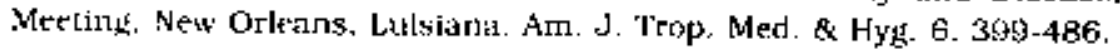

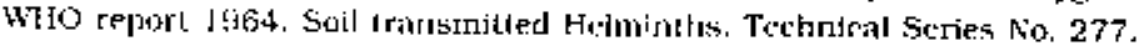

"Mothers shall suckle their children for two whole years . . ."

silgutan 2=233

Though Al-guran advocated mothers milk for thildren upto two years. the modern world for centuries preferred bottle fced. It Is however a correct realisation of the modern west that muther's milk is the best. The realisation of Gur'anic truth though late is commcndable. 